\title{
Attitudes towards leprosy in the outpatient population of dermatology clinics in Trinidad
}

\author{
M SUITE \& C GITTENS \\ Hansen's Disease Control Unit (Ministry of Health) 182 Western \\ Main Road, Cocorite, Trinidad, West Indies
}

Accepted for publication 9 December 1991

\begin{abstract}
Summary We interviewed a total of 92 dermatology clinic patients using a brief questionnaire to determine their knowledge, attitudes and beliefs about leprosy. This small survey helped to confirm our suspicions that some knowledge of leprosy is lacking and that much stigma still remains.
\end{abstract}

\section{Introduction}

In Trinidad and Tobago patients with leprosy have been cared for on a domiciliary basis since 1969, when admissions to the leprosarium at Chacachacare (an island off the northwestern coast of Trinidad) were discontinued. Leprosy control has been partially integrated with dermatology services since 1986 and patients are seen mainly as outpatients at skin clinics held at peripheral health centres, where both general skin patients and leprosy patients attend.

\section{Methods}

Patients were chosen at random from the skin clinic population at peripheral health centres and at 1 general hospital skin clinic. Patients under 18 years of age and those attending for leprosy were excluded. Anyone who might have had more than an average experience of leprosy, for example from nurses' training, or employment at Chacachacare, were also excluded. The interviewer was a medical social worker with a 3-year experience in dealing with leprosy patients. A set 12-item questionnaire was used.

\section{Results}

There were 92 respondents-72 female (78\%) and 20 male (22\%). (Percentages throughout are represented to the nearest whole digit). The predominance of females 
Table 1. Source of information about leprosy

\begin{tabular}{lcc}
\hline Source & Number & Percent \\
\hline Parents and other relatives & 33 & 36 \\
Know of persons suffering from leprosy & 17 & 18 \\
Media & 16 & 17 \\
School & 9 & 10 \\
Posters at health centres & 7 & 8 \\
Reading books & 4 & 4 \\
Did not remember & 3 & 3 \\
Never heard of leprosy & 6 & 6 \\
\hline
\end{tabular}

appears to hold for the clinic population as a whole and this may be due to the fact that women are more likely to notice and present for the treatment of skin complaints.

When questioned on the information sources concerning leprosy, the responses were sometimes vague, and people were unable to say with certainty where they had acquired their information. The results are summarized in Table 1 . The posters referred to had been recently displayed in Health Centres. Contrary to our expectations, most people did not relate leprosy to the biblical description.

Ideas about cause are shown in Table 2. Again, contrary to what we had experienced most people admitted ignorance, and only 4 (about $4 \%$ ) had concepts of a curse or punishment as the cause of leprosy.

Respondents were questioned about their level of education in an attempt to determine whether this had any bearing on their knowledge of the cause of leprosy. About half had completed primary school (see Table 3). Of the 19 who knew that leprosy was caused by a germ, 9 had reached secondary school level and the remaining 10 had attended primary school only. Of the 7 who thought it to be heredity, 5 had reached secondary level and 2 primary education. All of those who blamed a curse or punishment had completed primary school. Of those who knew nothing, 20 had secondary education, 36 primary education, 4 had no schooling and 2 had only preschool education.

Respondents were asked what leprosy looked like, and 37 respondents $(40 \%)$ knew that leprosy was associated with skin rashes. The responses included remarks such as 'skin with light patches', 'bumps on face', 'sores on the body'. However, only 1 person knew that the spots were sometimes associated with numbness; 31 respondents $(34 \%)$ had no idea how the disease presented; $16(17 \%)$ thought that deformities were present and their comments included 'fingers and feet clawed', 'eating away of fingers and toes',

Table 2. Causation of leprosy

\begin{tabular}{lcc}
\hline Response & Number & Percent \\
\hline Do not know & 62 & 67 \\
Germ & 19 & 21 \\
Heredity & 7 & 8 \\
Curse or punishment & 4 & 4 \\
Total & 92 & 100 \\
\hline
\end{tabular}


Table 3. Educational level

\begin{tabular}{lcr}
\hline Source & Number & Percent \\
\hline Primary school & 52 & 57 \\
Secondary school & 34 & 37 \\
Pre-school & 2 & 2 \\
No schooling & 4 & 4 \\
Total & 92 & 100 \\
\hline
\end{tabular}

Table 4. Curability of leprosy

\begin{tabular}{lcc}
\hline Response & Number & Percent \\
\hline Curable & 45 & 49 \\
Incurable & 14 & 15 \\
Do not know & 33 & 36 \\
Total & 92 & 100 \\
\hline
\end{tabular}

Table 5. Reaction to leprosy in self

\begin{tabular}{lrr}
\hline Response & Number & Percent \\
\hline Seek medical attention & 69 & 75 \\
Do not know what to do & 17 & 19 \\
'Prayers' & 2 & 2 \\
'Bush medicine' & 1 & 1 \\
Seek attention but avoid people & 1 & 1 \\
Does not believe it could happen & 1 & 1 \\
'Will die if it happens' & 1 & 1 \\
Total & 92 & 100 \\
\hline
\end{tabular}

'Deformities', 'disfigurement', 12 (13\%) believed that deformities accompanied the skin changes. We did not attempt to distinguish between presenting signs and stigmata.

About $50 \%$ of those questioned believed that leprosy is curable (see Table 4). We do not know whether their concept of cure related to resolution of skin lesions or deformities, and whether it related to their knowledge that a particularf orm of treatment is available.

Most people $(75=81 \%)$ claimed no contact with anyone with a diagnosis of leprosy. Of the 17 who knew of someone with leprosy, 12 claimed to have a friend or family member with leprosy; the remaining 5 had casual knowledge of 'someone in the neighbourhood'.

The reaction to contracting leprosy in the individual or a close friend or relative was positive in the majority of cases, with similar proportions seeking and accepting medical advice and supporting and encouraging friends to do the same (see Tables 5 and 6). However, they did not appear to expect friends and family to be as supportive of them (see Table 7).

Only 4 respondents considered leprosy a differential diagnosis for their own (non- 
Table 6. Response to family and friends contracting leprosy

\begin{tabular}{lcc}
\hline Response & Number & Percent \\
\hline Supportive & 64 & 70 \\
Do not know & 17 & 18 \\
Shun & 8 & 9 \\
'Prayers' & 2 & 2 \\
'Bush medicine' & 1 & 1 \\
Total & 92 & 100 \\
\hline
\end{tabular}

Table 7. Response of family and friends to respondent's diagnosis of leprosy

\begin{tabular}{lcc}
\hline Source & Number & Percent \\
\hline Dont know & 39 & 43 \\
Supportive & 34 & 37 \\
Shun & 15 & 16 \\
Family supportive, friends shun & 3 & 3 \\
Will support but still shun & 1 & 1 \\
Total & 92 & 100 \\
\hline
\end{tabular}

leprosy) skin complaints, 43 (47\%) felt they could contract leprosy, $22(24 \%)$ thought not and $30(33 \%)$ did not know.

The majority of individuals $(60=66 \%)$ did not know where leprosy patients are cared for; $18(20 \%)$ thought patients were still on the island of Chacachacare. Of the 14 who knew that they were in the community, 7 were definite about it, but the remaining 7 gave vague responses, e.g. 'some clinic', 'somewhere in Port of Spain'.

\section{Discussion}

We concluded that the general knowledge of leprosy was deficient. The receiving of secondary school education did not appear to influence that knowledge as is shown by questions about the cause.

Individuals seemed more likely to recall childhood memories. In some cases there had been recent viewing of leprosy on television and possibly some had heard a recent radio interview involving staff of the Leprosy Control Unit.

Contrary to our previous notions, the Bible did not feature as a significant source of knowledge, although we have had many queries in the past from people who believe that biblical leprosy is the same as that we see today.

There is one study from the English-speaking Caribbean (performed in Guyana) with which we can compare some of our results. Cook $^{1}$ reported that $61 \%$ of her respondents believed that leprosy was incurable. This is significantly greater than our $14 \%$. Her survey was performed before embarking on an educational programme. In Trinidad and Tobago, education about leprosy started receiving greater emphasis during the 1970s and 
so perhaps our group had an advantage- $52 \%$ of Cook's respondents associated leprosy with skin changes (our study-40\%), and $29 \%$ spoke of deformities or loss of extremities (our study-17\%). Our group therefore was only minimally more knowledgable about the signs. The knowledge of sensory loss in this disease was lacking. In our experience those who present with loss of feeling in their extremities sometimes believe that this is due to 'nerves', 'arthritis' or 'something lacking in the blood'. The notion of leprosy as a cause is usually absent.

While the majority suggested that they would respond favourably to the diagnosis of leprosy in themselves, in friends or relatives, by seeking medical attention and being supportive, they did not seem to expect the same response if the positions were reversed, in effect $64 \%$ of the respondents claimed that they would be supportive of friends and relatives who contracted leprosy, but only $50 \%$ of them expected support from others if they had the disease.

It is our experience that a common response to the diagnosis is to question the patients as to how they contracted leprosy and they are keen that other people should not know. In addition, patients are sometimes reluctant to tell other members of the immediate family, including spouses, that they have leprosy. In-laws seem to be particularly difficult to approach and contact examination sometimes becomes a ticklish issue. This reinforces our suspicion that the stigma still exists, although to a lesser extent than Cook demonstrated in Guyana.

As in Guyana, there is a persistent ignorance about the cause of leprosy, its symptoms, signs, and curability, which is an obstacle to the process of eradication. We believe that there must be a greater educational thrust beginning, perhaps, at primary school level. Emphasis must be placed on bacterial causation, the efficacy of modern chemotherapy, which quickly renders patients non-infectious, ${ }^{2}$ and the fact that early diagnosis and treatment may prevent deformities. Although leprosy seems to be less of a problem now in the Caribbean we must still not lose sight of its continued presence and importance.

\section{Reference}

1 Cook, Anne. An urban community's thoughts about leprosy; a survey in Guyana. Lepr Rev, 1982; 53: 285296.

2 Jopling WH, McDougall AC. Handbook of Leprosy, 4th Edn. Oxford: Heinemann Professional Publishing, 1988, p. 4. 


\section{Attitudes a l'égard de la lèpre chez la population visitant la consultation externe de} dermatologie à Trinidad

\section{Suite èt C Gittens}

Résumé Nous avons interrogé un total de 92 patients de la clinique de dermatologie en leur présentant un bref questionnaire pour déterminer leur connaissance, attitude et convictions au sujet de la lèpre. Cette petite enquète a contribué à confirmer nos soupçons, à savoir que la lèpre n'est pas suffisamment connue et qu'elle reste très stigmatisée.

\section{Actitudes a la lepra en la populación externa de las clínicas dermatológicas en Trinidad}

\section{Suite y C Gittens}

Resumen Entrevistamos un total de 92 pacientes de clínicas dermatológicas por medio de un cuestionario breve, para determinar los conocimientos, actitudes y creencias respecto a la lepra. Este pequeño estudio nos ayudó confirmar nuestras sospechas de que faltan algunos conocimientos y que persiste mucho dell estigma. 